\title{
Histological analysis of saphenous veins surgically harvested by with or without electrocautery
}

\author{
Rui Almeida ${ }^{1,2,3^{*}}$, Daniel Almeida ${ }^{1}$, Rodrigo Freitas $^{3}$, Carlos Floriano ${ }^{1}$ \\ From World Society of Cardiothoracic Surgeons 25th Anniversary Congress, Edinburgh \\ Edinburgh, UK. 19-22 September 2015
}

\section{Background/Introduction}

The use of electrocauterization in the harvesting of the saphenous vein, to be used as grafts in coronary artery bypass grafting (CABG) is a common practice in almost all units of cardiovascular surgery.

\section{Aims/Objectives}

To evaluate, if the use of electrocauterization, in the harvesting of the saphenous vein has a deleterious effect, in the histological aspect of the vein, and if it correlates to the clinical result.

\section{Method}

Twenty-four patients underwent CABG and in twelve of them electrocautery was used (Group 1) to harvest the saphenous vein and in another twelve it was not (Group 2 ). Vein segments were sent for analysis after fixed in $10 \%$ formalin for 24 hours. These segments were vertically cut and two fragments were removed for histological analysis. They were stained with hematoxylin and eosin according to the normal protocol. All samples were analyzed by a blinded observer, which looked for morphological changes, especially acute ones in the endothelium, muscle tunics and adventitia. The acute changes investigated were: necrosis, degeneration, inflammation, thrombosis, structural rupture signs and the presence of hemorrhage. The mid-term results of the grafts were observed clinically.

\section{Results}

In both the groups there was no change in the endothelium or limiting membrane. In three cases (25\%) of Group 1 there was the appearance of pyknotic nuclei, likely exaggerated by cauterization. In one case (8.33\%), the Group 2 had a recent hemorrhage adventitia. The

${ }^{1}$ Faculdade Assis Gurgacz,Cascavel, Paraná, Brazil

Full list of author information is available at the end of the article blind observer only managed to identify a use case cautery one sample, in Group 1, apart from those who had pyknotic nuclei.

\section{Discussion/Conclusion}

Despite the small sample, collected, it was possible to identify four cases where cauterization was used for the dissection of the saphenous vein. There was no correlation of the same with the clinical course of patients.

\section{Authors' details}

${ }^{1}$ Faculdade Assis Gurgacz,Cascavel, Paraná, Brazil. ${ }^{2}$ Parana Western State University, Cascavel, Paraná, Brazil. ${ }^{3}$ ICCOP, Cascavel, Paraná, Brazil.

\section{Published: 16 December 2015}

\section{doi:10.1186/1749-8090-10-S1-A185}

Cite this article as: Almeida et al:: Histological analysis of saphenous veins surgically harvested by with or without electrocautery. Journal of Cardiothoracic Surgery 2015 10(Suppl 1):A185.
Submit your next manuscript to BioMed Central and take full advantage of:

- Convenient online submission

- Thorough peer review

- No space constraints or color figure charges

- Immediate publication on acceptance

- Inclusion in PubMed, CAS, Scopus and Google Scholar

- Research which is freely available for redistribution
() Biomed Central 